\title{
Additional treatment with Carnoy solution in surgical therapy of ameloblastomas:
}

\section{Case report}

\section{Tratamento adicional com solução de Carnoy na terapia cirúrgica de ameloblastomas: Relato de} caso

Tratamiento adicional con solución de Carnoy en terapia quirúrgica de ameloblastomas: Reporte de caso

Thames Bruno Barbosa Cavalcanti ORCID: https://orcid.org/0000-0001-5064-4005

Universidade Federal de Pernambuco, Brazil Universidade de Pernambuco, Brazil E-mail: thamesbruno@gmail.com

Rosa Rayanne Lins de Souza ORCID: https://orcid.org/0000-0002-9534-605X

Universidade de Pernambuco, Brazil E-mail: rosaalins27@hotmail.com

Ivson Souza Catunda

ORCID: https://orcid.org/0000-0003-2916-7683

Universidade de Pernambuco, Brazil

E-mail: ivsoncatunda@gmail.com

Priscilla Sarmento Pinto

ORCID: https://orcid.org/0000-0002-2376-4383 Universidade de Pernambuco, Brazil

Universidade Federal de Pernambuco, Brazil

E-mail: priscillasarmentop@gmail.com

Ruan de Sousa Viana

ORCID: https://orcid.org/0000-0003-1542-4554 Universidade de Pernambuco, Brazil

E-mail: ruansv@hotmail.com

Igor Chaves Gama da Silva

ORCID: https://orcid.org/0000-0002-9581-6621

Universidade de Pernambuco, Brasil

E-mail: iigor_chaves@hotmail.com

Sthephany Ellen Mendes de Melo

ORCID: https://orcid.org/0000-0003-0556-7199

Universidade de Pernambuco, Brazil

E-mail: sthephany_mendes@live.com

Felipe Ricardo Cisneiros Brito

ORCID: https://orcid.org/0000-0001-8222-9033

Faculdade de Odontologia de Pernambuco, Brazil

E-mail: felipe.cisneiros@upe.br

Greiciane Miguel de Azevedo Santos

ORCID: https://orcid.org/0000-0001-7876-3655

Faculdade de Odontologia de Pernambuco, Brazil

E-mail: greiciane_azevedo@outlook.com

Abdiel Ortega Gôndola

ORCID: https://orcid.org/0000-0002-8487-1422

Hospital da Restauração, Brazil

E-mail: ortegagondoa@hotmail.com

\begin{abstract}
Introduction: Ameloblastoma is a benign neoplasm characterized by the proliferation of odontogenic epithelium that mainly affects the gnathic bones and, due to its invasive and expansive growth, presents high rates of recurrence to surgical treatment. Among the most conservative treatments are enucleation and marsupialization; among radicals, resections are more widespread. Objective: The objective is to present, through a case report, conservative surgical treatment with enucleation followed by the use of the Carnoy solution. Case report: A 24-year-old male patient arrives at the outpatient clinic of Hospital da Restauração with painful complaints of mild and constant intensity in the region of the left mandibular angle, with an evolution of three weeks. After a panoramic X-ray, the presence of the included
\end{abstract}


38 tooth was associated with an extensive unilocular radiolucent lesion, surrounding the angle and mandibular ramus. Preoperative examinations were performed for incisional biopsy. Histopathological diagnosis was unicystic ameloblastoma. In view of the histopathology obtained, we opted for enucleation of the lesion with concomitant use of direct Carnoy solution in the region of the lesion. Discussion: The choice of therapeutic behavior depends on the size, type of lesion, location and histopathology. After the surgical decision, a radiographic clinical follow-up is necessary to assess possible recurrences. Carnoy's solution is a cauterizing agent with moderate tissue penetration, rapid local fixation and hemostatic action, whose surgical use in cystic lesions has occurred since the beginning of the 20th century. Conclusion: Conservative treatment with the enucleation technique followed by complementary therapy using Carnoy's solution proved to be quite effective.

Keywords: Ameloblastoma; Complementary therapies; Neoplasms.

\section{Resumo}

Introdução: $\mathrm{O}$ ameloblastoma é uma neoplasia benigna caracterizada pela proliferação do epitélio odontogênico que acomete principalmente os ossos gnáticos e, devido ao seu crescimento invasivo e expansivo, apresenta altos índices de recidiva ao tratamento cirúrgico. Entre os tratamentos mais conservadores estão enucleação e marsupialização; entre os radicais as ressecções são mais difundidas. Objetivo: Objetiva-se apresentar, por meio de um relato de caso, o tratamento cirúrgico conservador com enucleação seguida do uso da solução de Carnoy. Relato de caso: Paciente do sexo masculino, 24 anos, chega ao ambulatório do Hospital da Restauração com queixas dolorosas de intensidade leve e constante em região do ângulo mandibular esquerdo, com evolução de três semanas. Após uma radiografia panorâmica, a presença do dente 38 incluído foi associada a uma lesão radiolúcida unilocular extensa, circundando o ân.gulo e ramo mandibular. Foram realizados exames pré-operatórios para biópsia incisional. O diagnóstico histopatológico foi ameloblastoma unicístico. Diante da histopatologia obtida, optou-se pela enucleação da lesão com uso concomitante de solução Carnoy direta na região da lesão. Discussão: A escolha do comportamento terapêutico depende do tamanho, tipo de lesão, localização e histopatologia. Após a decisão cirúrgica, um acompanhamento clínico radiográfico é necessário para avaliar possíveis recidivas. A solução de Carnoy é um agente cauterizante com penetração tecidual moderada, fixação local rápida e ação hemostática, cujo uso cirúrgico nas lesões císticas ocorre desde o início do século XX. Conclusão: O tratamento conservador com a técnica de enucleação seguida de terapia complementar com uso de solução de Carnoy se mostrou bastante eficaz.

Palavras-chave: Ameloblastoma; Terapias complementares; Neoplasias.

\section{Resumen}

Introducción: El ameloblastoma es una neoplasia benigna caracterizada por la proliferación de epitelio odontogénico que afecta principalmente a los huesos gnáticos y, debido a su crecimiento invasivo y expansivo, presenta altas tasas de recurrencia al tratamiento quirúrgico. Entre los tratamientos más conservadores se encuentran la enucleación y marsupialización; entre los radicales, las resecciones están más extendidas. Objetivo: El objetivo es presentar, a través de un caso clínico, el tratamiento quirúrgico conservador con enucleación seguida del uso de la solución de Carnoy. Caso clínico: Un paciente masculino de 24 años llega al ambulatorio del Hospital da Restauração con quejas dolorosas de intensidad leve y constante en la región del ángulo mandibular izquierdo, con una evolución de tres semanas. Después de una radiografía panorámica, la presencia del 38 diente incluido se asoció con una lesión radiolúcida unilocular extensa, que rodea el ángulo y la rama mandibular. Se realizaron exámenes preoperatorios para biopsia incisional. El diagnóstico histopatológico fue de ameloblastoma uniquístico. Dada la histopatología obtenida, optamos por la enucleación de la lesión con el uso concomitante de una solución de Carnoy directa en la región de la lesión. Discusión: La elección de la conducta terapéutica depende del tamaño, tipo de lesión, localización e histopatología. Tras la decisión quirúrgica, es necesario un seguimiento clínico radiográfico para valorar posibles recidivas. La solución de Carnoy es un agente cauterizante con penetración tisular moderada, rápida fijación local y acción hemostática, cuyo uso quirúrgico en lesiones quísticas se da desde principios del siglo XX. Conclusión: El tratamiento conservador con técnica de enucleación seguida de terapia complementaria con solución de Carnoy resultó ser bastante eficaz.

Palabras clave: Ameloblastoma; Terapias complementarias; Neoplasias.

\section{Introduction}

Ameloblastoma is a benign, slow-growing, locally invasive and expansive tumor, presenting high rates of relapse to surgical treatment (Aragão 2014; Effiom et al., 2018; Sheela et al., 2019; Saraiya 2020; Palanisamy \& Jenzer 2020; GonzálezGonzález et al., 2020; Chai et al., 2019). It is an epithelial odontogenic tumor and its frequency is equal to that of all odontogenic tumors together, excluding odontomas (Fregnani et al., 2010; Palanisamy \& Jenzer 2020; Kreppel \& Zöller 2018). Its predilection occurs in the mandible in $85 \%$ of cases and the posterior region, branch and mandibular angle are the most affected, comprising 75\% of mandibular cases (Neville 2011; Palanisamy \& Jenzer 2020; Chai et al., 2019). The tumor may 
occur at any age; however, there is predominance between the third and fifth decade of life (Effiom et al., 2018; Palanisamy \& Jenzer 2020; Sheela et al., 2019; Chai et al., 2019). In the initial phase, ameloblastomas present scarce clinical features, without symptomatology, making the early diagnosis rare (Kruschewsky et al., 2010). Usually, they present a slow growth, often associated with the expansion of the cortical bone, which leads to facial deformities (Paikkatt et al., 2007; Kreppel \& Zöller 2018). When signs or symptoms are present, patients usually report painless swelling associated with paresthesia or malocclusion, but most cases are discovered by routine radiographs (Kruschewsky et al., 2010).

In radiographic studies, most of the lesions are found as radiolucent, multilocular with well-defined limits that may resemble "soap bubbles" or "honeycomb", however, due to their ability to infiltrate the spaces bone marrow, its limits sometimes do not reflect the actual impairment of the lesion (Aragão 2014; Krishnapillai \& Angadi 2010; Palanisamy \& Jenzer 2020). In this context, Ameloblastoma, according to its clinical and radiographic characteristics, is classified into three types (Neagu et al., 2019): multicystic, unicystic and peripheral (extraosseous). There is also the malignant form that has few cases described in the literature (Palanisamy \& Jenzer, 2020). Histologically, multicystic ameloblastomas can be classified in follicular plexiform, acanthomatous, granular, baseloid and desmoplastic cells. The unicistics can be classified in intraluminal, mural and extramural (Neville 2011; González-González et al., 2020), the mural variant tending to repeat itself (Marimuthu et al., 2020).

The surgical therapy of ameloblastoma can have several types of approach, from the most conservative to the most radical and the professional who will do the approach should choose the best treatment option (Carvalho et al., 2010; Neagu et al., 2019). Among the most conservative treatments are enucleation and marsupialization (Chai et al., 2019); among radicals resections are more widespread. The choice of therapeutic behavior depends on the size, type of lesion, location and histopathology (Palanisamy \& Jenzer 2020). Radical interventions have a lower recurrence rate (Saraiya 2020), but most of them create aesthetic and functional damages that are difficult to reconstruct (Effiom et al., 2018; Chai et al., 2019). All extirpular surgical procedures aim at total removal of the lesion and elimination of remaining cells, so conservative treatments have a lower spectrum of action compared to radicals (Pogrel \& Montes 2009). However, some authors like Lee et al., (2004) believe that conservative treatment creates a better quality of life and Marimuthu et al., 2020 reports the importance of enucleation and the use of Carnoy's solution even in pediatric patients, a population in which the occurrence of ameloblastoma is rare (Sheela et al., 2019).

On the other hand, for the multicystic variety, the conservative approach is not recommended, being this one more indicated in the unicystic variety, in all its variants. In order to give a greater safety to the conservative treatment, additional procedures like the use of chemical substances (carnoy solution) or thermal (cryotherapy) are recommended for the treatment of the bed with elimination of possible remaining cells. The ameloblastomas present high rates of relapses (Neagu et al., 2019), so after the treatment, it is necessary that the preservation is done for a period of at least 5 years (Lee et al., 2004).

Carnoy's solution is a cauterizing agent with moderate tissue penetration, rapid local fixation and hemostatic action, whose surgical use in cystic lesions has occurred since the beginning of the 20th century. Its application to the bone shop after invasive lesion removal provides safety margin by chemical necrosis of up to $1.5 \mathrm{~mm}$ depth (Williams \& Connor 1994). Each $10 \mathrm{~mL}$ of solution contains $6 \mathrm{~mL}$ of absolute alcohol; $3 \mathrm{~mL}$ of chloroform and $1 \mathrm{~mL}$ of glacial acetic acid associated with $1 \mathrm{~g}$ of ferric chloride and can be used for three minutes after enucleation directly in the bone shop (Lee et al., 2004).

Therefore, the objective of this study is to present the resolution of the clinical case of unicystic ameloblastoma, in which it was decided to enucleate the lesion with concomitant use of a direct carnoy solution in the region of the lesion in order to guarantee an optimal prognosis for the patient. 


\section{Methodology}

This is a clinical case study that is qualitative, descriptive and produced by the technique of direct observation. According to Pereira et al. (2018), research with this character aims to elucidate a particular subject and study it thoroughly, with the patient's permission, through access to medical records, clinical examination, laboratory and image exams available, with the researcher being the instrument paramount to this process. Here, we respect all the ethical principles proposed by the Declaration of Helsinki, upon the patient's consent to their clinical information. The patient in question consented to the study and disclosure of his case, signing the Informed Consent Form provided by our team.

\section{Case Report}

A 24-year-old male patient, brown, without systemic diseases, arrives at the outpatient clinic of the hospital of the restoration with painful complaints of light and constant intensity in a region of left mandibular angle, with evolution of three weeks. Physical examination showed no clinical change, only pain on palpation in the region of the mandibular vestibule. After a panoramic radiograph, the presence of the included 38 tooth was associated with an extensive unilocular radiolucent lesion with a diameter of more or less $6 \mathrm{~cm}$ surrounding the angle and mandibular branch (Figure 1).

Figure 1 - Diagnostic radiography showing unilocular lesion associated with the tooth.

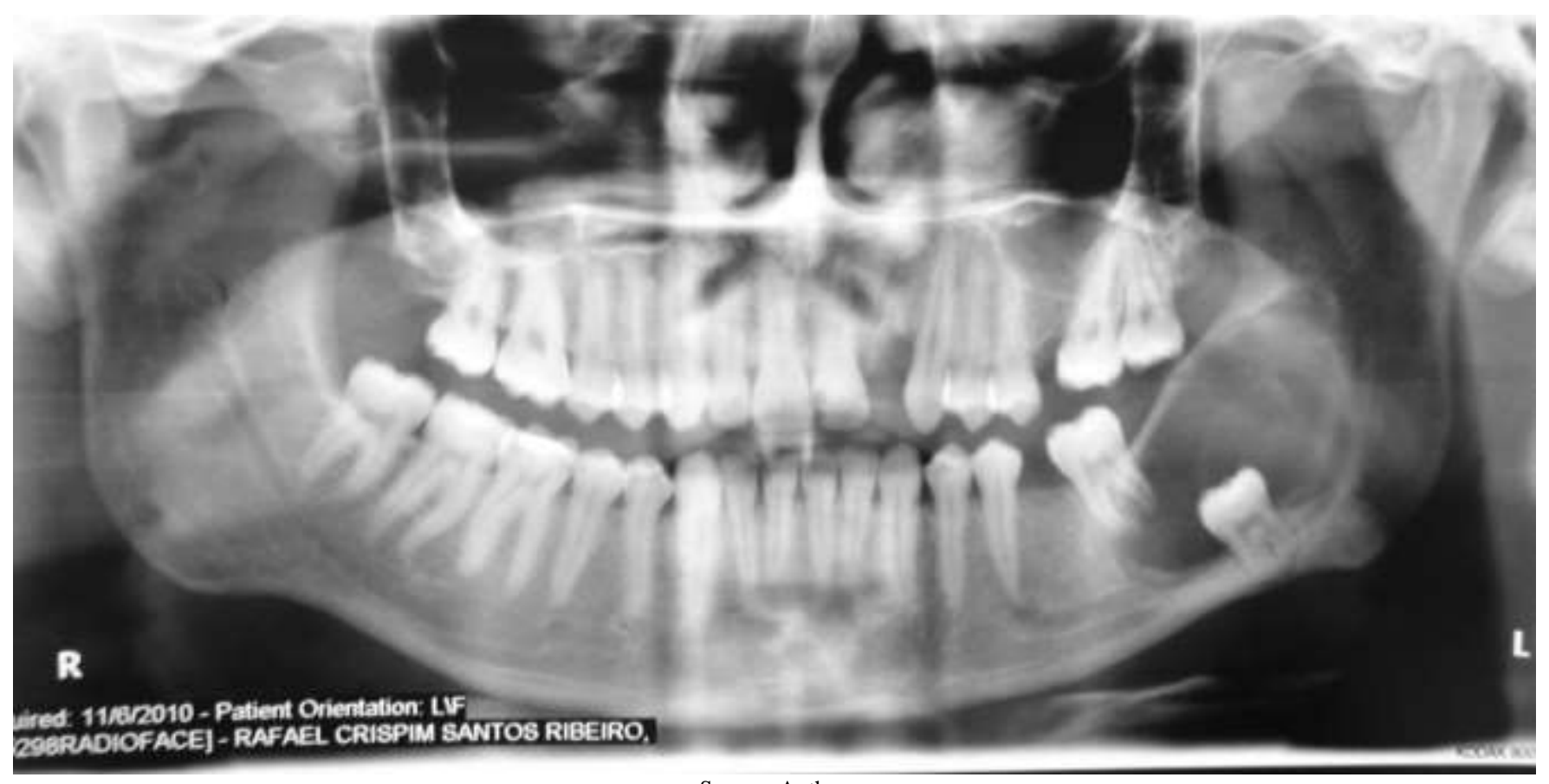

Source: Authors.

The lesion was discovered, and after that, preoperative exams were performed for an incisional biopsy procedure. The histopathological diagnosis was unicystic ameloblastoma. In view of the obtained histopathology, it was chosen the enucleation of the lesion with concomitant use of direct carnoy solution in the lesion region (Figure 2). 
Research, Society and Development, v. 10, n. 6, e15610615235, 2021

(CC BY 4.0) | ISSN 2525-3409 | DOI: http://dx.doi.org/10.33448/rsd-v10i6.15235

Figure 2 - In the surgical approach, enucleation was performed with concomitant use of carnoy solution in the lesion region.

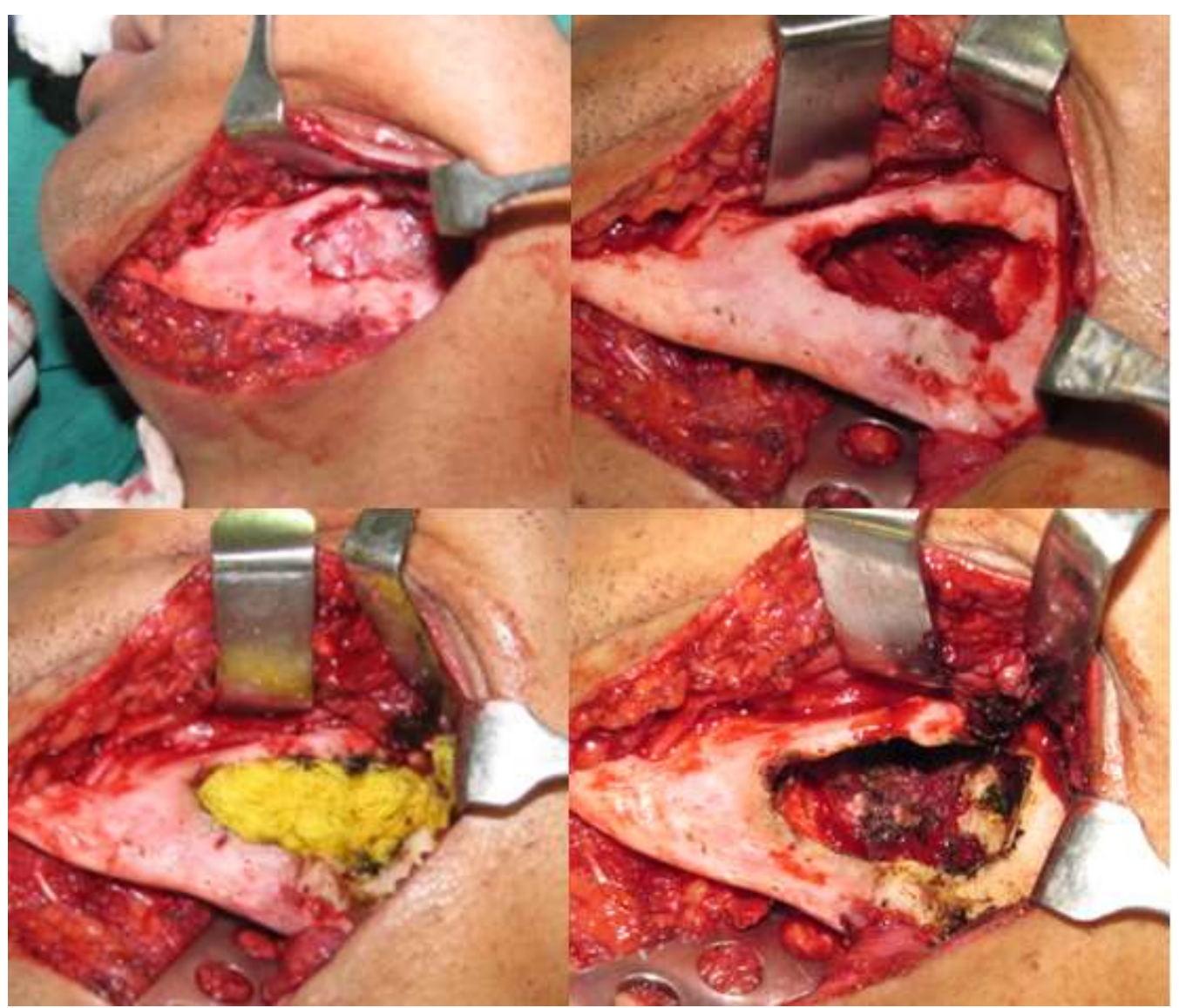

Source: Authors.

During the period of convalescence, it was necessary to maintain the patient with maxillary mandibular block for 30 days to reduce the risk of pathological fracture and remained in clinical radiographic follow-up for the following periods: immediate, 3 months, 6 months, 1 year and 2 years (Figure 3). 
Figure 3 - Follow-up X-rays, 3 months, 6 months, 1 year and 2 years.

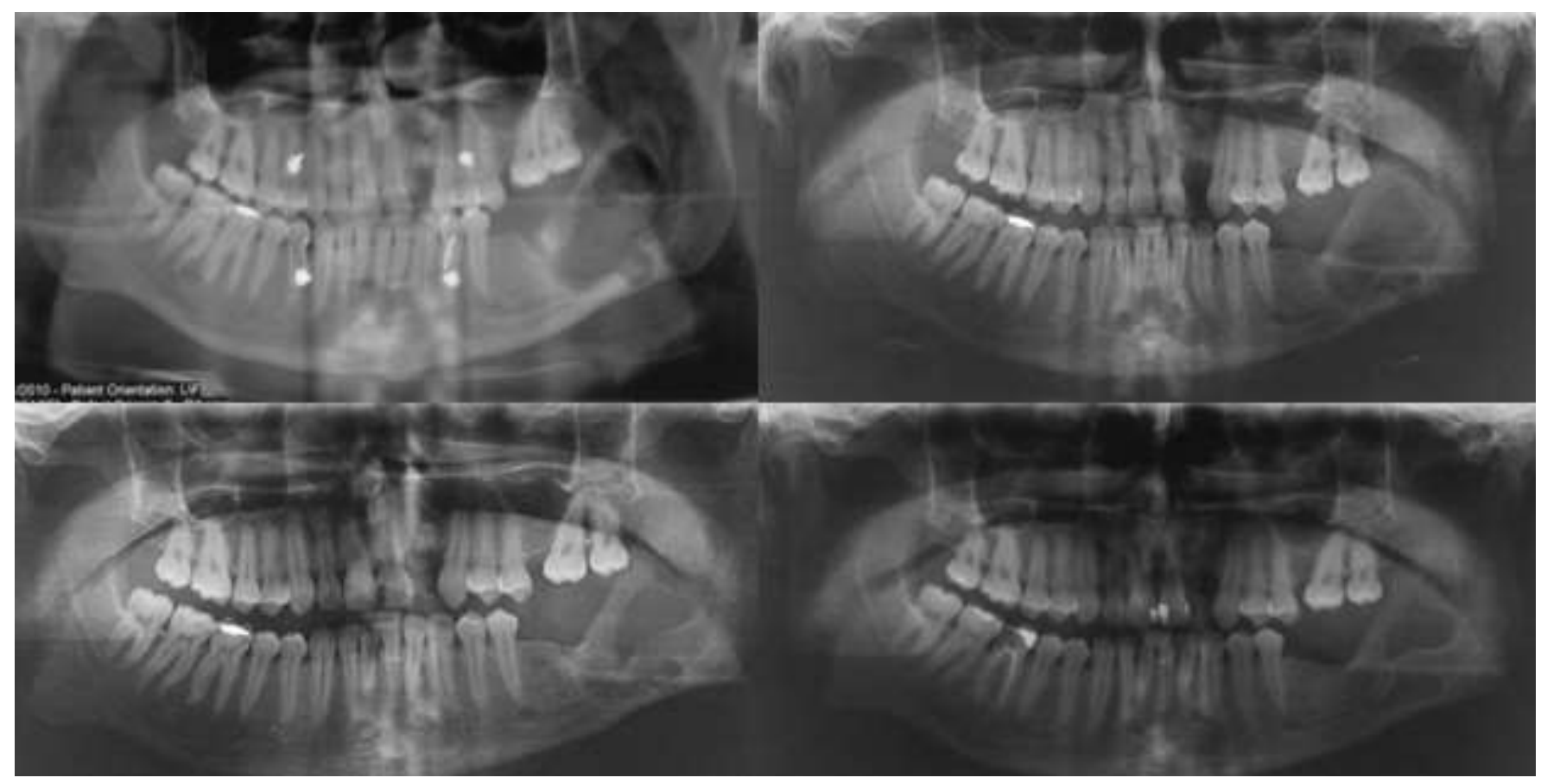

Source: Authors.

\section{Discussion}

Ameloblastoma is a benign neoplasm characterized by proliferation of the odontogenic epithelium (Neville 2011; Palanisamy \& Jenzer 2020). Because it is a potentially invasive type of tumor and has a good number of histopathological variables, there is a need for additional histopathological and radiographic exams so that there is an accurate diagnosis and, from this, the best form of treatment is chosen (Paikkatt et al., 2007; Carvalho et al., 2010; González-González et al., 2020). The data found in the literature related to the location and prevalence of age are confirmed by the clinical findings described in the case, corroborating the work of Fregnani et al, (2010), where the majority of tumors occur between 20 and 30 years and mainly affect region of mandibular angle.

According to Neville et al. (2011) and Palanisamy and Jenzer (2020), ameloblastoma generally evolves without symptoms, since pain and paresthesia are rarely reported. In the present case, the clinical findings diverge from the literature, since the patient was taken to the hospital because of constant painful symptoms of mild intensity in the region where the tumor was located. Also important was the association of the tumor with the crown of an unbroken tooth, which is also characteristic of lesions such as dentigerous cyst and odontogenic keratocystic. Thus, it is important to perform a histopathological examination that, besides excluding differential diagnoses, is fundamental for the surgical planning and treatment of the lesion (Neagu et al., 2019).

The histopathological and radiographic exams were extremely important and served as the basis for the decision making regarding the treatment of the tumor. Because it is a unicystic ameloblastoma, it was chosen a conservative treatment, as is the case with enucleation. Because of the high rates of relapses consistent with the conservative treatment described in the literature (Chai et al., 2019), it was used carnoy's solution to provide a margin of safety, removing epithelial remnants that may promote recurrence of the lesion (Krishnapillai \& Angadi 2010).

Placement of Carnoy solution used directly in the surgical shop for three minutes after enucleation may reduce the chance of relapse, as well as the use of cryotherapy (Williams \& Connor 1994; Costa et al., 2019). Both methods promote 
cauterization and bone necrosis. However, the carnoy solution is more resistant to cryotherapy in both its handling and postoperative complications (Lee et al., 2004).

Two-year follow-up did not reveal findings consistent with recurrence of tumor lesion, thus showing that the conservative treatment with safety margin used in this case is viable. However, there is still a need for radiographic and, when necessary, histopathological clinical follow-up for a period of 10 years to evaluate possible relapse (Kruschewsky et al., 2010; Aragão 2014).

\section{Conclusion}

The definitive treatment for ameloblastomas is surgical and the histopathological diagnosis of the type of ameloblastoma is fundamental for the surgical decision, and the conservative treatment of the unicystic lesions is effective with the enucleation technique followed by complementary therapy with the use of a solution of Carnoy.

\section{References}

Aragão, M. A. Caracterizando o ameloblastoma: relato de caso clínico. 2014. 20f. Trabalho de Conclusão de Curso. Universidade Estadual da Paraíba.

Carvalho, K. M., Dhupar, A., Spadigam, A., \& Syed, S. (2017). Ameloblastoma: A 16-year clinicopathological study on Goan population. Indian Journal of Pathology and Microbiology, 60(2), 157.

Chai, K. S., Omar, F. H., Saad, A. Z. M., Sulaiman, W. A. W., \& Halim, A. S. (2019). A 20-year experience of immediate mandibular reconstruction using free fibula osteocutaneous flaps following ameloblastoma resection: Radical resection, outcomes, and recurrence. Archives of plastic surgery, $46(5), 426$.

Costa, D. C., de O, S. L., Queiroz, S. I., Dantas, W. R., Da Silva, J. S., \& Germano, A. R. (2019). Relapses after using Carnoy's solution in treating aggressive benign odontogenic lesions. Minerva stomatologica, 68(5), 242-248.

Effiom, O. A., Ogundana, O. M., Akinshipo, A. O., \& Akintoye, S. O. (2018). Ameloblastoma: current etiopathological concepts and management. Oral diseases, 24(3), 307-316.

Fregnani, E. R., da Cruz Perez, D. E., De Almeida, O. P., Kowalski, L. P., Soares, F. A., \& de Abreu Alves, F. (2010). Clinicopathological study and treatment outcomes of 121 cases of ameloblastomas. International journal of oral and maxillofacial surgery, 39(2), $145-149$.

González-González, R., López-Verdín, S., Lavalle-Carrasco, J., Molina-Frechero, N., Isiordia-Espinoza, M., Carreón-Burciaga, R. G., \& Bologna-Molina, R. (2020). Current concepts in ameloblastoma-targeted therapies in B-raf proto-oncogene serine/threonine kinase V600E mutation: systematic review. World journal of clinical oncology, 11(1), 31.

Kreppel, M., \& Zöller, J. (2018). Ameloblastoma-Clinical, radiological, and therapeutic findings. Oral diseases, 24(1-2), 63-66.

Krishnapillai, R., \& Angadi, P. V. (2010). A clinical, radiographic, and histologic review of 73 cases of ameloblastoma in an Indian population. Quintessence international, 41(5).

Kruschewsky, L. D. S., Cincurá, C. A. R. O. L. I. N. A., Teixeira, F. A., \& Mello Filho, F. V. (2010). Ameloblastoma: aspectos clínicos e terapêuticos. Rev bras cir craniomaxilofac, 13(4), 2415.

Lee, P. K., Samman, N., \& Ng, I. O. (2004). Unicystic ameloblastoma-use of Carnoy's solution after enucleation. International journal of oral and maxillofacial surgery, 33(3), 263-267.

Marimuthu, L., Kumar, S., Shenoy, V., Afradh, M., \& Paranthaman, A. (2020). Mural Variant of Unicystic Ameloblastoma in a Pediatric Patient: A Rare Case Report. Cureus, 12(12).

Neagu, D., Escuder-de la Torre, O., Vázquez-Mahía, I., Carral-Roura, N., Rubín-Roger, G., Penedo-Vázquez, Á., \& López-Cedrún, J. L. (2019). Surgical management of ameloblastoma. Review of literature. Journal of clinical and experimental dentistry, 11(1), e70.

Neville, B. (2011). Patologia oral e maxilofacial. Elsevier Brasil.

Paikkatt, V. J., Sreedharan, S., \& Kannan, V. P. (2007). Unicystic ameloblastoma of the maxilla: a case report. Journal of Indian society of pedodontics and preventive dentistry, 25(2), 106.

Palanisamy, J. C., \& Jenzer, A. C. (2019). Cancer, Ameloblastoma.

Pereira, A. S., Shitsuka, D. M., Parreira, F. J., \& Shitsuka, R. (2018). Metodologia da pesquisa científica: UFSM.

Pogrel, M. A., \& Montes, D. M. (2009). Is there a role for enucleation in the management of ameloblastoma? International journal of oral and maxillofacial surgery, 38(8), 807-812. 
Research, Society and Development, v. 10, n. 6, e15610615235, 2021

(CC BY 4.0) | ISSN 2525-3409 | DOI: http://dx.doi.org/10.33448/rsd-v10i6.15235

Saraiya, H. A. (2020). Wide Excision with Immediate Reconstruction of the Mandible Using Free Fibular Flap in Ameloblastoma of the Mandible-A Need of Time: Our Experience of 37 Cases. Indian Journal of Plastic Surgery: Official Publication of the Association of Plastic Surgeons of India, $53(3), 363$.

Sheela, S., Singer, S. R., Braidy, H. F., Alhatem, A., \& Creanga, A. G. (2019). Maxillary ameloblastoma in an 8-year-old child: A case report with a review of the literature. Imaging science in dentistry, 49(3), 241.

Williams, T. P., \& Connor Jr, F. A. (1994). Surgical management of the odontogenic keratocyst: aggressive approach. Journal of oral and maxillofacial surgery, 52(9), 964-966. 